\title{
REDEFINING CITIES IN VIEW OF CLIMATIC CHANGES "SPONGE CITY" - EXAMPLES OF SOLUTIONS IN CHINESE CITIES AT RISK OF FLOODING - WUHAN, CHANGDE AND JINHUA
}

\author{
Eliza Maciejewska ${ }^{\bowtie}$ \\ Faculty of Civil Engineering, Warsaw University of Technology
}

\begin{abstract}
The article is focused on the problem of green infrastructure, which effectively helps to reduce the effects of floods and water deficit in cities. It presents examples of good practices implemented in China. In the end of 2014, China's national government initiated the "sponge city" project. A "sponge city" is a city built around the concept of managing water in an ecologically sustainable way by imitating natural hydrological cycles in the city, which translates into the restoration of the ability to absorb, infiltrate, store and purify rainwater in urbanized, highly sealed spaces. In "sponge cities", flood risk management is included in the mainstream of urban planning and has the appropriate legal framework. The intention is to improve urban resilience through rainwater capture, storage and use by means of green roofs, pavements made of permeable materials, tumbles, rigoles, retention ponds, water squares, rain gardens and creating wetlands parks.
\end{abstract}

Key words: water retention, green infrastructure, "sponge city", flood threat, China

\section{INTRODUCTION}

In recent decades, climate change is significantly affecting the functioning of cities. These processes are manifested by increasingly occurring extreme phenomena, such as drought or floods (Lejcuś et al., 2017). At the same time, the last century has been a period of the rapid development of cities due to social, economic, political and technological changes, which is contributing to growing anthropopressure on the environment. Climate change, along with the increasing flood risk and the experience of natural disasters in recent decades, have changed the view of flood protection. It was considered that the existing methods involving the development of technical infrastructure, among others construction of embankments, storage reservoirs, and canals are insufficient. Since the Direc- tive 2007/60/EC on the assessment and management of flood risk was introduced, the preferred approach to managing flood risk is co-existence with water. The new water paradigm proclaims the need to create space for water. This slogan is implemented through the sustainable management of rainwater, surface water and underground water. In the cities, along the rivers, new waterfronts and buildings are created, designed to minimize the effects of the flood wave transition, e.g. the Dryline by BIG for southern Manhattan.

In urban areas, the water cycle in nature is disturbed. Rainwater should soak into the ground and be naturally filtered through the soil, and then feed groundwater resources. Often, however, a densely built-up urban structure prevents this process. During rainfall, the water goes directly to the rainwater drainage system. Grey, blue and green infrastructure 
are currently the central elements of sustainable planning, in addition to long-term land management. Grey infrastructure encompasses the technical infrastructure below ground such as pipes and pumps (Sharma, Gardner \& Begbie, 2019).

\section{THE "SPONGE CITY" CONCEPT}

A "sponge city" is designed to passively absorb, clean and use rainfall in an ecologically friendly way that reduces dangerous and polluted runoff (Khan \& Afroz, 2018). Solutions in this area include, among others pavements and roads made of permeable materials, rainwater harvesting, green roofs, tumbles, rigoles, retention ponds and lakes, water squares and wetlands parks. The "sponge city" concept is based on the imitation of natural hydrological cycles in nature in the city, which translates into the restoration of the ability to absorb, infiltrate, store and purify rainwater in urbanized, highly sealed spaces (Fig. 1). In "sponge cities", flood risk management is included in the mainstream of urban planning and has the appropriate legal framework (Zevenbergen, Fu \& Pathirana, 2018a). This concept is implemented, among others in Germany, China and the USA.
The benefits of implementation of these techniques are: the reduction of frequency and severity of floods, better water quality and reduction of water consumption per person. The "sponge city" is not only the solution to "too much water" problem, but also deals with "water shortages" by means of reusing rain water.

This project draws inspiration from other global concepts for storm water and rainwater management, such as: WSUD (water sensitive urban design), which started to take off in Australia in 1990s, LID (low impact development) in the USA, LIUDD (low impact urban design and development), BMPs (best management practices), GI (green infrastructure), SUDS (sustainable urban drainage system), "sponge city" (Wagner \& Krauze, 2014; Sharma et al., 2019). According to Sharma et al. (2019), the specific drivers for this innovation also varied between countries: North America initially focused on water quality improvement, while much of Europe was driven by the need to reduce local flooding and overflows from their "combined sewers" carrying both storm water and sewage. Australia's goal was to protect water quality and waterway ecosystems and littoral zones. China, on the one hand, is facing urban water shortages and on the other is regularly flooded.

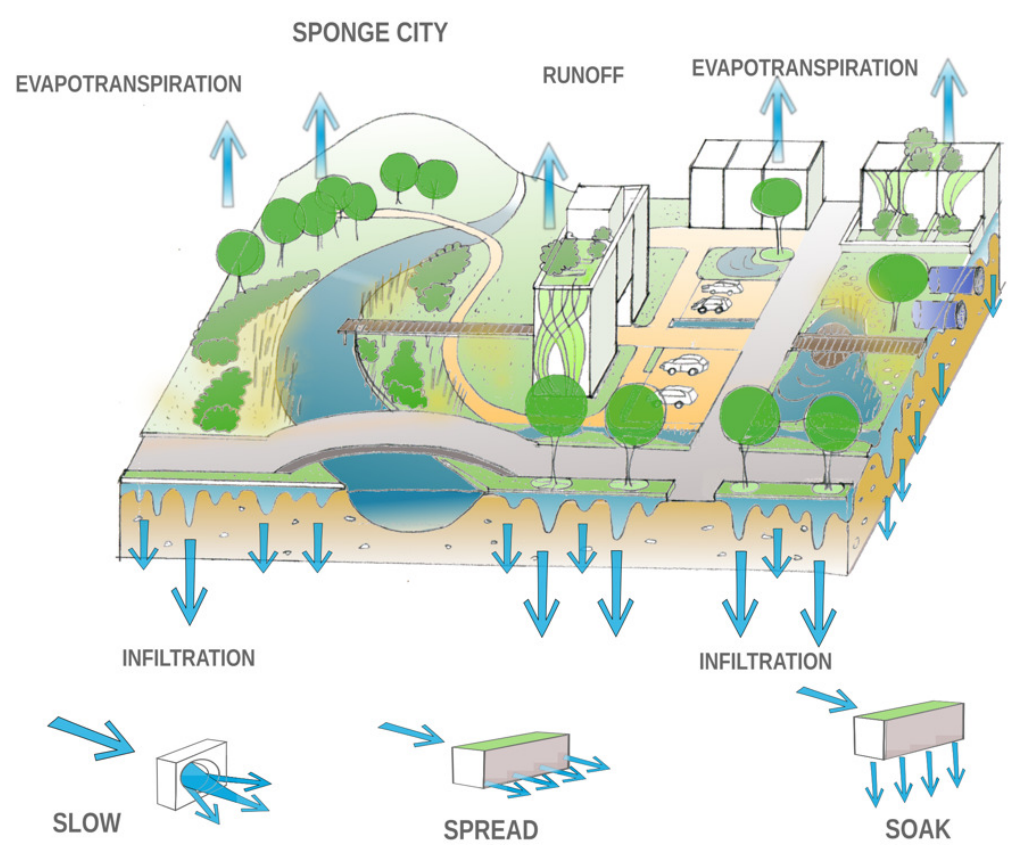

Fig. 1. "Sponge city" (illustration by author) 


\section{CREATING “SPONGE CITY” IN CHINA}

China has experienced great urban expansion and growth in wealth since last three decades. The urban population has increased a six-fold in number since 1980 s, which is about 750 million people. At present, the urban population in China is more than $54 \%$ of the total population. Beijing, has witnessed more than a doubling of the total land coverage in the past 10 years. Several devastating flood events occurred in the same period whereas affected city areas of Beijing have been constructed in the last two decades.

Various studies have indicated that one of the major causes of Beijing's recent flood events is a lack of surplus capacity of the drainage system to cope with extreme weather events (Zevenbergen et al., 2018a). In over $90 \%$ of Chinese cities, the design of urban flooding mitigation measures is linked to traditional engineering infrastructure (i.e. floodgates, concrete infrastructure and oversized drains) that aim to drain urban discharges as quickly as possible to downstream outlets (larger rivers, lakes and coasts). In Shenzhen for example, the main drainage outlet is the Shenzhen River, which subsequently discharges into the Pearl River Estuary and the South China Sea (Chan et al., 2018, after SZWB, 2012). Since 2008, the number of Chinese cities affected by floods has more than doubled (Dutch Water Sector, 2016). Due to the rapid progress of industrialization and urbanization, and the increase in the frequency of extreme weather events, water problems in cities have become significant in the socio-political discourse in the country over the last two decades.

The central government of China promotes "sponge cities" as a national, holistic strategy to address urban flooding, because they are designed to offer "a more sustainable, integrative solution to the urban flooding problem than traditional storm water management practices, and one that is more closely related to the eco-city and low-carbon city approach" (Yang \& Lin, 2015). The "sponge city" project was initiated in China at the end of 2014. At that time, the first 16 pilot cities were selected, including Wuhan and Shanghai, and then the programme was expanded to include another 14 new cities in 2016. Pilot cities are located in different climate areas (Zevenbergen et al., 2018a). Other
Chinese cities include Chongqing, Qian'an, Xiamen and Nanning.

The goal of the ambitious "sponge city" project is to transform $20 \%$ of selected cities according to the "sponge cities" by 2020 and $80 \%$ by 2030 . The "sponge city" project will result in an infrastructure that holds, cleans and drains water, using an ecologically-friendly approach. Each city will receive from the central government up to 63 million USD per year for three years to implement projects (Dutch Water Sector, 2016).

\section{WUHAN}

Wuhan is one of the first of 16 cities in China to launch project "sponge city", an integrated water management initiative driven by the Central Government (Dutch Water Sector, 2016). The city has 12 million inhabitants and is located at the confluence of the Yangtze and Han rivers. Water pollution is a considerable issue in Wuhan. In 2014, four out of eleven rivers did not meet prescribed water quality standards. For historical reasons, these river areas were designed as "discharge control areas" (areas with intensified drain outlets), from which partially treated industrial and domestic sewage were discharged into the Yangtze and Han rivers (Dai, van Rijswick, Driessen \& Keessen, 2017). In Wuhan a rapidly expanding concrete and asphalt landscape had created severe flooding risk. In 2016, torrential rains hit the city, cutting off entire neighbourhoods. The Wuhan pilot started operations in mid-2015 and was planned to finish by the end of 2017. A Dutch engineering group - Arcadis implements the project and helps to shape policies in Wuhan (Fig. 2).

The Wuhan Sponge City Programme deals with reducing waterlogging as well as increasing water quality via the ecological remediation of existing urban water systems. Actions are taken to construct blue and green spaces to restore the city's capacity to absorb, infiltrate, store, purify and drain (rain) water. During first phase of the project from 2015 to 2017, there were 389 so-called sponge projects implemented: such as urban gardens and waterbodies in parks, roads, residential communities and two new rainwater pump stations providing at least $25 \%$ of the city's water. The area of "sponge city" transformation will cover $38 \mathrm{~m}^{2}$ 


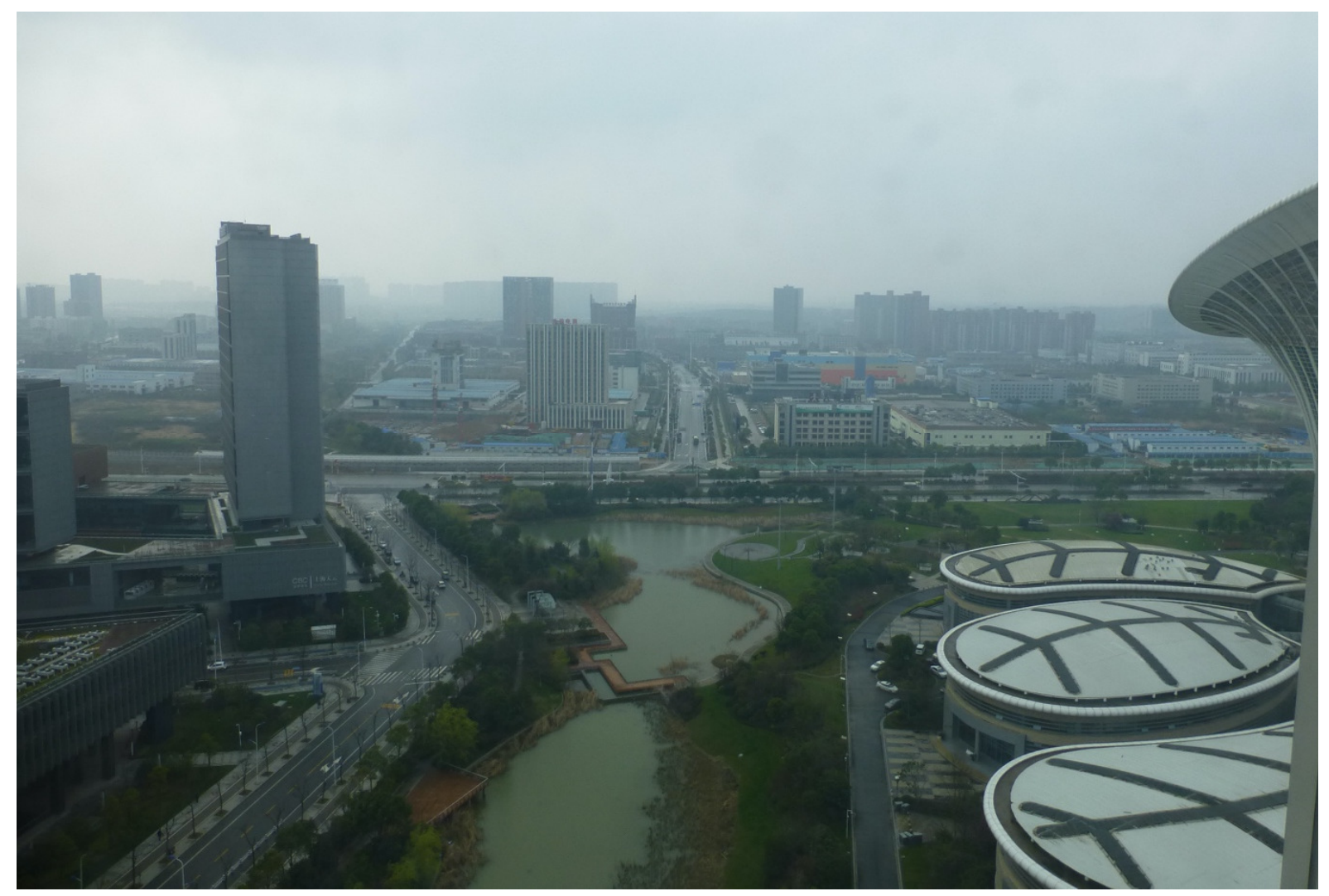

Fig. 2. Wuhan, China Wuhan (https://upload.wikimedia.org/wikipedia/commons/7/7a/Wuhan_-_Future_City_-_Area_ G_-_P1530349.JPG, access 10.12.2019)

of the city and provide habitat for plants and wildlife. Furthermore, drain pipelines will be improved, 13 ports and channels will be repaired, and at least one lake will be ecologically restored. Overall, the project is expected to reduce the occurrence of severe water-logging events from once annually to once in 10 years in the pilot zone, a strong start to adapting the city to climate change (Brown \& Sako, 2016).

It is worth to mention that Garden Expo Park, built in Wuhan between 2012 and 2015, is now promoted as a good example of a "sponge" project. The park covers an area of around $30 \mathrm{~km}^{2}$. Although it was built on the biggest rubbish dump site in the city, it has now become a popular entertainment site. Sponge-like concepts were adopted in the park: collecting rainwater by using pervious concrete, purifying rainwater by building a rainwater garden, and watering plants with rainwater. The rainwater collecting system now collects and retains around $70 \%$ of the rainwater. Since the park was completed, around 600 households that had previously moved out from the rubbish dump site have moved back. The park won the Prize of China Habitat Environment in 2016, which is the highest prize for habitat environment construction in China. The success of the park has encouraged the municipal government to construct similar projects (Dai et al., 2017).

Benefits of "sponge city" solutions in Wuhan:

- Environmental benefits: it is estimated that initiatives in the project will result in a $70 \%$ reduction in pollution carried via runoff in certain catchment areas.

- Social benefits: it is estimated that 20,000 new jobs will be created through the Wuhan Sponge City Programme.

- Health benefits: the project increases the quality of drinking water for the people of Wuhan.

- Economic benefits: by focusing on the protection and utilization of the natural water system, the 
Wuhan Sponge City Programme prevents considerable costs caused by damage from waterlogging.

- Increase of the value of land and houses located in the area covered by the "sponge city" infrastructure. According to survey conducted by Zhang, Zevenbergen, Rabé and Jiang (2018), about $83 \%$ of respondents believed that "sponge city" construction would increase the value of houses located in the area covered by the construction, and $67 \%$ of respondents thought that "sponge city" construction would increase the land value of the area that the construction covers. Most respondents assumed that the range of increase would be less than $5 \%$ of the property's original value.

Although Wuhan is undergoing an urban and ecological makeover - from permeable pavements to wetlands and artificial ponds - designed to absorb storm water and even reuse it later, the process of constructing the "sponge city" has fallen behind schedule, mainly due to insufficient funds (Zhang et al., 2018).

\section{CHANGDE}

Changde city is located in the north part of Hunan province. It was an important political, economic, and cultural centre in the Ming dynasty because the city has rich water systems and convenient transportation. However, currently the city has polluted and smelly rivers, canals, and lakes (Zeng, Song \& Chen, 2004) The area, a low-lying land river basin that experiences heavy rainfall, is regularly flooded.

Chicago architectural office UrbanLab was commissioned to design the masterplan for a new centre within the larger city of Changde. This project is devised as a "new model for the future". Architects and engineers from Chicago are of great experience, because they applied many "sponge city" solutions in the USA before.

UrbanLab's master plan for Changde is a new district that will accommodate 600,000 people in 5 square miles $\left(13 \mathrm{~km}^{2}\right)$. At the centre of the site is a highly polluted lake that is prone to flooding. UrbanLab's principle design concept is to reimagine water as an amenity instead of a problem for people (UrbanLab). The lake is re-planned as a "central water park" for the entire city. There will be no defences against water. The idea of the project is to put space for water to flow at the centre of the city urban plan, putting major buildings on islands in an enormous central lake. Canal-lined streets that UrbanLab call "Eco-Boulevards" connect eight districts. "Eco-Boulevards" pre-treat storm water runoff. Eco-Boulevards are connected to additional water filtering infrastructures such as tree-lined feeder roads, storm water parks, and in-block rain gardens. Together, the streets and open green spaces are a porous framework, or holistic "sponge city," which naturally absorbs and cleans rainwater before entering the lake. In the lake, a group of new islands are planned. The "Central Business District Island" contains the most prominent new commercial buildings, and a chain of "Cultural Islands" contains new civic venues and gardens. UrbanLab continues to consult with Changde's Planning Bureau to help implement the master plan.

To solve the problem of flood and water pollution, eight water projects - as a part of "sponge city" programme will be constructed along the Chuan Zi River, which is a branch of the Yangzi River. The water projects are expected to improve the water quality and recover the natural appearance of the Chuan Zi River as well as decrease flood frequency in Changde city (Liang, 2018). One of the projects: the Chuan project consists of rainwater harvesting plants and an ecological purification area. The ecological purification area consists of different kinds of plants, including phytoplankton and reeds. In the rainy season, rainwater harvesting plants can spare rainwater and help to release the stress of flood. The rainwater is purified by the rainwater harvesting plants and the ecological purification area before flowing into the river. This ensures that the pollution substance cannot flow into the river (Liang, 2018).

Advantages of the "sponge city" in Changde:

- Environmental benefits: highly efficient bus transit system, reducing energy use and pollution. Bus stops and transfer nodes are planned within a 10-minute pedestrian walk to all new developments.

- Visionary solutions for other cities: a combination of a dense metropolis with a nature setting - a new way of thinking about the city of the future.

- Ecological benefits: different kinds of plants helps to reduce the pollution in the lake and river, water filtering infrastructures to help clean the lake. 
- Social benefits: the purification area is a wetland park for all residents nearby.

- Flood defence: the ecological purification area has the function of water reservation.

\section{YANWEIZHOU PARK, JINHUA}

Yanweizhou Park is situated in the heart of Jinhua, a city with a population of over one million. It covers more than 64 acres ( 26 ha) of the last undeveloped natural riparian in place where the Wuyi River and Yiwu River converge to form the Jinhua River. The name Yanweizhou literally means "the sparrow tail".

Due to its monsoon climate, Jinhua suffers from annual flooding. For years, the strategy to control flooding was building stronger and taller concrete floodwalls. It was yield solution, the city was gaining cheap land for urban development. These walls along the riverbanks and riparian flood plains destroyed the close relationship between the city, the vegetation, and the water, while ultimately exacerbating the destructive force of the annual floods.

Following this formula, hard high walls have been built, or were planned to be built, to protect the last patch of riparian wetland (Yanweizhou) from the 20 -year and 50-year floods. These floodwalls would create dry parkland above the water, but destroy the lush and dynamic wetland ecosystem. The landscape architect devised a contrasting solution to stop the construction of the concrete floodwall and to demolish others. The idea of the Yanweizhou project is to "make friends" with flooding by using a cut-and-fill strategy to balance earthwork and by creating a water-resilient terraced river embankment that is covered with flood adapted native vegetation (Turenscape, 2014).

Architects from Turenscape designed a water resilient terrain and plantings to adapt to the monsoon floods. A resilient bridge and a paths system were designed to adapt to the dynamic water currents and people flows. The system of bridge and paths connect the city with nature and connect the past to the future. Architects created resilient spaces to fulfil the need for temporary, intensive use by the audience from the opera house, also adaptable for daily use by people seeking intimate and shaded spaces. It was achieved through the meandering vegetated terraces, curvilinear paths, a serpentine bridge, circular bio-swales and planting beds, and curved benches. The existing building was integrated into the surrounding environment to create a cohesive landscape. The project has given the city a new identity. It is now acclaimed as very poetic, picturesque and worth seeing city landscape (Fig. 3).

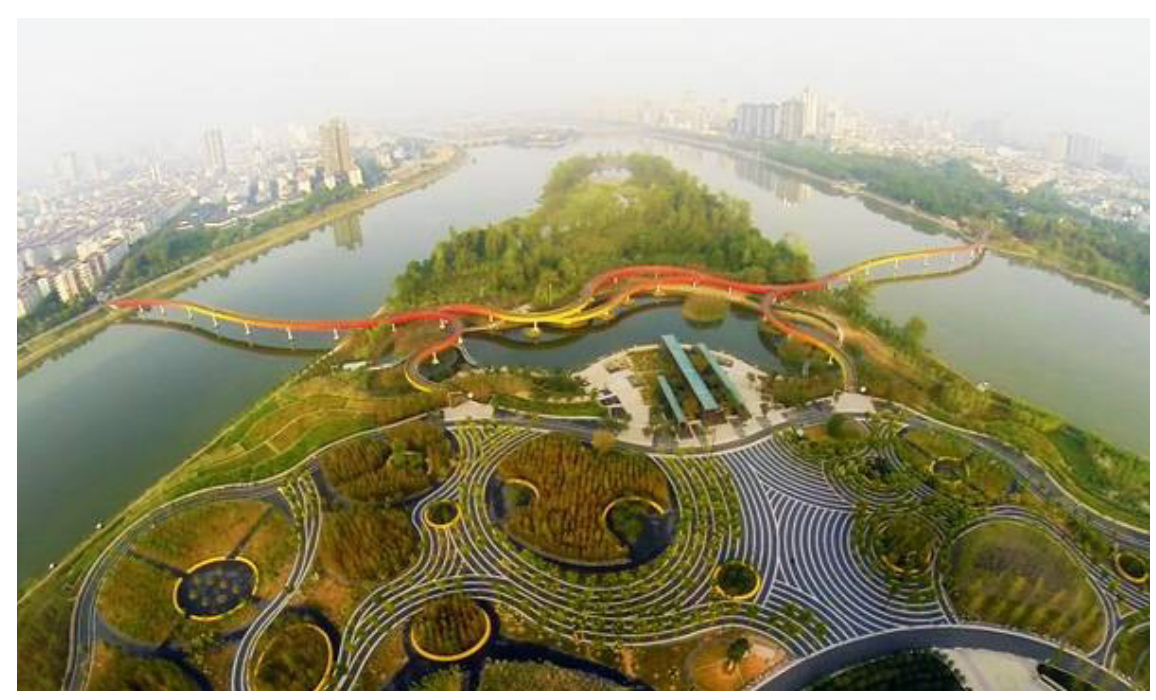

Fig. 3. Yanweizhou Park, Jinhua City, China (photo by Turenscape, http://sztuka-krajobrazu.pl/1614/artykul/ekologicznypark-posrod-trzech-rzek, access 12.12.2019) 
The park is a proven success. The architects managed to preserve the remaining patch of riparian habitat and also to provide amenities to the residents of the dense urban centre. The cultural identity of the city was strengthened by a connection to the natural riparian landscape. After it opened in May 2014, an average of 40,000 visitors used the park and bridge each day.

Benefits of "sponge city" solution:

- Environmental benefits: enhance natural ecosystems and enabling nature-based solutions that improve urban habitats for birds and other organisms.

- Health and well-being benefits: providing pleasing space for the people that live and work in urban environments.

- Flood mitigation benefits.

\section{SUMMARY}

The benefits of investments related to green urban infrastructure bring effects not only in the field of flood protection, for which they were mainly developed. These actions can deliver multiple benefits:

- storm water quality improvements,

- flood control and reuse of rainwater to help mitigate the impacts of drought,

- reduction of economic losses due to flooding,

- enhancement of landscape amenity,

- healthy living environment - quality of life improvement,

- ecosystem health,

- air quality improvement,

- reduction of urban heat islands.

According to Zevenbergen, $\mathrm{Fu}$ and Pathirana (2018b), China has the potential to play a leading role internationally in sustainable urban water management in the coming decade. The reasons that support this thesis are:

- Existing urban environmental problems in China (such as water, air quality) are so pressing that they provide immediate-term initiatives to invest resources to manage these problems. The "sponge city" programme is a good example of such an immediate-term incentive.

- China's ambition is to become a leader in science and technology globally. Therefore, the country is increasing the budget for innovation and strengthening its engagement in international research, such as in the Chinese European Water partnership (CEWP).

- It is a matter of time, when a combination of home-grown innovations, joint ventures with foreign companies, and modifications to existing technology will change significantly the way in which the water challenges of Chinese cities will be managed.

The "sponge city" programme arouses hot disputes in the Chinese academic research field. From the urban planning point of view, the programme can help to improve the urban water environment and decrease the use of concrete in the cities (Shi et al., 2013; Yu et al., 2015). Nevertheless, from the perspective of urban management, the feasibility of the programme is doubtful, because there is lack of coordination and cooperation within different departments in a Chinese city, which are the precondition of successful implementation of the "sponge city" programme (Song \& Zhang, 2016). Among engineers there are supporters and opponents of the programme. The supporters begin to design all types of water treatment projects based on the concept of the "sponge city", while the opponents think the programme focuses on rainwater harvesting or flooding treatment projects. Their actions are considered not sufficient for city flood prevention (Sang \& Yang, 2016; Song \& Zhang, 2016).

Investment in "sponge city" initiatives is difficult, with only small interest from domestic investors. There is hardly any analysis of the "sponge city" programme from an economic perspective in the literature. Some articles only point out the possible financial problems, such as sufficient investment or sources of finance (Zhang et al., 2018). There is no extensive economic feasibility analysis. There are recommendations that the government should slow down the implementation of this ambitious programme and help society and the private sector to catch up and effectively participate. It could be conducted by strengthening international cooperation and collaboration and gaining from the experience of institutions around the world. 
Maciejewska, E. (2020). Redefining cities in view of climatic changes "sponge city" - examples of solutions in Chinese cities at risk of flooding - Wuhan, Changde and Jinhua. Acta Sci. Pol. Architectura, 19 (1), 11-19. doi: 10.22630/ASPA.2020.19.1.2

According to Liang (2018), whether the "sponge city" programme can be implemented successfully depends on an effective cost recovery plan made by the local government or a reasonable business model for the water projects. If the financial problem is solved, the "sponge city" programme could largely help to improve the water environment, protect sponge bodies such as natural rivers, lakes or wetlands and decrease the pressure of flooding.

\section{REFERENCES}

Brown, J. \& Sako, D. (2016). Cities100. 100 solutions for climate actions in cities. Copenhagen: Sustainia. Retrieved from https://www.mm.dk/pdffiles/CITIES100 2016.pdf [access 09.03.2019].

Chan, F. K. S., Griffiths, J. A., Higgitt, D., Xu, S., Zhu, F., Tang, Y.-T., Xu, Y. \& Thorne, C. R. (2018). "Sponge City" in China - A breakthrough of planning and flood risk management in the urban context. Land Use Policy, 76, 772-778.

Dai, L., Rijswick, H. F. M. W. van, Driessen, P. P. J. \& Keessen, A. M. (2017). Governance of the Sponge City Programme in China with Wuhan as a case study. International Journal of Water Resources Development, 34, 578-596.

Directive 2007/60/EC of the European Parliament and of the Council of 23 October 2007 on the asfessment and management of flood risk. OJ L 288/27 of 06.11.2007.

Dutch Water Sector (2016). Arcadis appointed as principal consultant for Sponge City programme in Wuhan, China. Retrieved from https://www.dutchwatersector. com/news/arcadis-appointed-as-principal-consultantfor-sponge-city-programme-in-wuhan-china [access 12.12.2019].

Khan, I. \& Afroz, R. (2018). Adapting Sponge City Concept for Dhaka City. IOSR Journal of Environmental Science, Toxicology and Food Technology, 12 (2), 16-18.

Lejcuś, K., Burszta-Adamiak, E., Dąbrowska, J., Wróblewska, K., Orzeszyna, H., Śpitalniak, M. \& Misiewicz, J. (2017). Katalog dobrych praktyk - zasady zrównoważonego gospodarowania wodami opadowymi pochodzacymi z nawierzchni pasów drogowych. Wrocław: Wydział Inżynierii Miejskiej.
Liang, X. (2018). Economic evaluation of the Sponge City program in China: Case study of Changde city. Central Asian Journal of Water Research, 4 (1), 63-78.

Sang, Y.-F. \& Yang, M. (2016). Urban waterlogs control in China: more effective strategies and actions are needed. Natural Hazards, 85, 1291-1294.

Sharma, A. K., Gardner, T. \& Begbie, D. (2019). Approaches to Water Sensitive Urban Design. Potential, Design, Ecological Health, Urban Greening, Economics, Policies, and Community Perceptions. Amsterdam: Elsevier.

Shi, R., Liu, N., Li, L., Ye, L., Liu, X. \& Guo, G. (2013). Application of rainstorm and flood inundation model in flood disaster economic loss evaluation. Torrential Rain and Disasters, 32 (4), 379-384.

Song, F. \& Zhang, H. (2016). Problems and strategies in the construction and management of Chinese sponge city. Urban Development Studies, 23 (10), 99-104.

Turenscape (2014). A Resilient Landscape: Yanweizhou Park in Jinhua City. Retrieved from https://www.turenscape. com/en/project/detail/4629.html [access 09.03.2019].

Wagner, I. \& Krauze, K. (2014). Jak bezpiecznie zatrzymać wodę opadową w mieście? Narzędzia techniczne. In T. Bergier, J. Kronenberg \& I. Wagner (Eds.), Zrównoważony Rozwój - Zastosowania: Woda w mieście (pp. 75-91). Kraków: Fundacja Sendzimira.

Yang, Y., Lin, G. (2015). A review on sponge city. South Architecture Journal, 1 (3), 59-64.

Yu, K., Li, D., Yuan, H., Fu, W., Qiao, Q. \& Wang, S. (2015). "Sponge City": Theory and Practice. City Planning Review, 39 (6), 26-36.

Zeng, W., Song, Q. \& Chen, R. (2004). Ecological and environmental water requirements of urban river course: taking Chuanzihe river as an example. Ecology and Environment, 13 (4), 528-531.

Zevenbergen, Ch., Fu, D. \& Pathirana, A. (2018a). Sponge Cities: Emerging Approaches, Challenges and Opportunities. Basel-Beijing-Wuhan-Barcelona-Belgrade: MDPI.

Zevenbergen, Ch., Fu, D. \& Pathirana, A. (2018b). Transitioning to Sponge Cities: Challenges and Opportunities to Address Urban Water Problems in China. Water, $10(9), 2-13$.

Zhang, S., Zevenbergen, Ch., Rabé, P. \& Jiang, Y. (2018). The Influences of Sponge City on Property Values in Wuhan, China. Water, 10 (6), 1-20. 


\section{REDEFINING CITIES IN VIEW OF CLIMATIC CHANGES „SPONGE CITY” - PRZYKŁADY ROZWIAZZAŃ W CHIŃSKICH MIASTACH ZAGROŻONYCH POWODZIA - WUHAN, CHANGDE I JINHUA}

\section{STRESZCZENIE}

Artykuł porusza kwestię zielonej infrastruktury, która skutecznie pomaga zmniejszyć skutki powodzi i deficytu wody w miastach. Przedstawiono przykłady dobrych praktyk wdrażanych w Chinach. Pod koniec 2014 r. rząd chiński zainicjował narodowy program „sponge city” („miasto-gąbka”). Koncepcja „sponge city" opiera się na wdrożeniu w miastach zrównoważonej gospodarki wodnej naśladującej naturalne procesy w cyklu hydrologicznym. Celem realizowania tej koncepcji jest przywrócenie zdolności do wchłaniania, infiltracji, retencji i oczyszczania wody deszczowej w zurbanizowanych, wysoce „uszczelnionych” przestrzeniach. W „miastach-gąbkach” zarządzanie ryzykiem powodziowym jest połączone z planowaniem przestrzennym i ma odpowiednie ramy prawne. Dzięki kompleksowemu zarządzaniu ryzykiem powodziowym można zwiększyć odporność miasta na ekstremalne sytuacje powodziowe poprzez zatrzymywanie, magazynowanie, a następnie wykorzystanie wody deszczowej. Realizowane jest to za pomocą projektowanej zielonej infrastruktury w postaci: zielonych dachów, chodników wykonanych z przepuszczalnych materiałów, rigoli, stawów retencyjnych, kwartałów wodnych, deszczowych ogrodów, oraz poprzez tworzenie parków wodnych.

Słowa kluczowe: retencja wody, zielona infrastruktura, „miasto-gąbka”, zagrożenie powodziowe, Chiny 